\title{
Brave new globalisation
}

\section{by Taina Ahtela}

The global economy. Global information exchange. Global politics. Global markets. Global values. Global responsibility. Globalization, "globality", globalism, the "G-word", "mondialisation du monde" or "worldization of the world". Globalization defines both the development optimists' greatest dreams as well as its critics' worst nightmares. Its progression cannot be stopped, and mostly the real issue in discussions about globalization concerns the rules that regulate it or rather the lack of them. Whether one loves globalization or hates it, few doubt its existence. But the only thing about globalization that is certain seems to be that there is no agreement either on the concept nor its substance. With its self-legitimating symptoms it makes talk of the end of history or ideology seem slightly amusing.

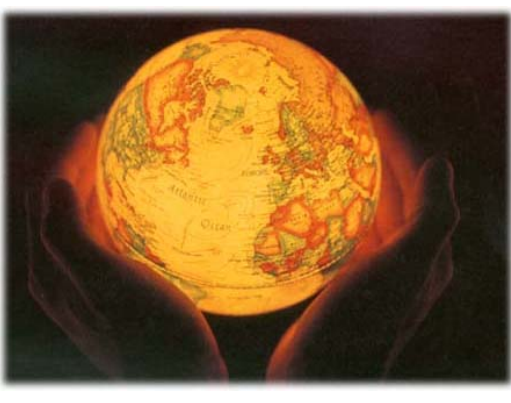

which transforms the world without revolution or even political debate- "business as usual".

The critical attitude towards globalization usually presents criticism towards the ideology of the so-called "globalism". What is meant by globalism is the dominance of neo-liberalism in the interpretations of the international economy which has been made possible by globalization's political and ideological side. Globalism sees the dismanteling of political administration and the weakening of the role of the state as indicators of progress and, according to Ulrich Beck, all other dimensions as subordinate to this linear economic view. It dissolves the distinction between politics and economics, implicating that political action is replaceable by world markets. It is ironic that also the opponents of globalization have adopted this perception of the hegemony of world markets.

Has a significant strucutural transformation truly taken place and if so, what is it like; what is even meant by globalization? Two books, four specialists and a question: is there something new in all of this?

\section{Globalization and its criticism}

The discussion on globalization is dispersed. The is no hope for an all-encompassing theory, when there isn't even a working set of scientific concepts applicable to globalization. It is a different thing to speak of economic, cultural or communications-technological globalization. Is politics globalized? Globalization is often seen as representing the unavoidable reality, the historical development phase, which, due to its focus on economic aspects, sometimes seems even value-free and outside political control.

Ulrich Beck, who is known for his concept of the "risk society" remarks that despite its value-free rhetoric, globalization hasn't meant the end of politics but rather its extension outside the conceptual structure of the nationstate, outside the traditional dichotomy "political" and "non-political". (What is globalization? Beck 1999). This perception is common to almost all analyses of globalization and globalization is in fact most often defined as the extension of action (whether this be related to economics, political control, the definition of law or culture) outside the traditional level of the nation-state. It is of central importance, that no longer are individual actors' and, most of all, corporations' opportunities for influence limited to the sphere economic action. At its extreme it is a question of a "market-anarchic minimalist state utopia"
I asked four experts in their own fields how they understand the concept of globalization and how it presents itself to them. Common to all, was that globalization was not seen as a structurally new phenomenon, although, perhaps as something of a new degree, as deepening internationalization or as globalization amongst other phases of globalization. Between the lines were also apparent the threats emanating from globalism. The globalizing economy hasn't given birth to a functioning political, social and legal control mechanism at the global level. And I quote Beck: "a world society without a world state and without a world government".

\section{The empire of the liberal market economy}

Is there something new about globalization from an economic perspective then? Grahame Thompson and Paul Hirst question the concept of globalization from an economic perspective in their book Globalization in Question (Polity Press, 1996). According to them globalization has become a fashionable concept, which perceives the fundamental dynamic of the world economy as having changed structurally. But Hirst and Thompson reject the idea that the accelerating internationalization of the economy that has taken place after the 1970s reflects the formation of a "global" ecomic structure as something distict from previous internationalization. They also demonstrate that the international economy was partly even more integrated at the turn of the $20^{\text {th }}$ century than now. And on the question of transnational corporations, Hirst and Thompson claim that the national level has not lost its meaning. Quite the opposite actually, the central actors in the 
tions that have a national base.

Also the director of the Department of Economics at the University of Helsinki, Tapio Palokangas says that no qualitative break has taken place. Globalization has been happening gradually for centuries, although while progressing, it has affected institutions; the economic units have grown in size. But he still emphasizes, that although therewere, for example, no customs or passport formalities at the turn of the $20^{\text {th }}$ century, now they are being given up because of ecomic and not political reasons. When asked what an economist means when speaking of globalization, Palokangas says that ecomists have spoken of internationalization for centuries. "Now we can of course speak of globalization, which is the exact same thing. Actually, based on these previously mentioned reasons economists don't even use the concept".

From the point of view of traditional development studies and the group of developing countries, globalization reflects the politics which have defined the developing countries' position in the international economy for the past 15-20 years. Pertti Multanen from the Department of Development Studies (HU) emphasizes that independent of globalization and the ideology of globalism, the central questions, such as indebtedness, are old. "The image of globalization in the era of free international trade doesn't apply to developing countries. They still have significant obstacles to bringing their products to the world markets." This issue is closely related to the falling prices of raw materials, which goes far back in history by way of colonialism, and which has accelerated during the era of globalization. If we observe the concrete development of the past 20 years, we see that the results are really bad- in practice globalization has, in its current form, meant the isolation of the group of developing countries and the deepening of their societal crisis. Expressly due to the almost total lack of mutuality and equality, in the future there will have to be a discussion, which will decisively transform the concepts that are related to the liberalist, moneratist economic perception of, for example the role of the state in development. In the developing countries, the societal crises are so deep that their resolutions will require a democratically led state.

\section{Global regulation, please?}

There have been essential transforma-

tions in societal development during the past years., such as the birth of the "information society" and the increased mobility of capital. Problems have arisen that cannot be dealt with at the national level. But globalization itself is more than these developments, according to Burkhard Auffermann who specializes in international politics "Too often it is forgotten, that globalization is age old. One should remember, that European welfare has been based for many centuries on the exploitation of colonies." From the point of view of political research the principal challenges involve the grave disappearance of opportunities for democratic means of action and influence in the current state of globalization. As power internationalizes through the financial markets, does the action of citizens also become more international? Even at the level of the EU there is talk of the democratic defecit. "The EU at least has some institutions, through which citizens have the possibilty to influence policy-making. At the global level there is none." The issue there is the effectiveness of international non-govenmental organizations.

The director of the Katti-intitute (Intitute of Economic Law) Veijo Heiskanen (on leave of absence) also doesn't see globalization as a historically unique phenomenon, but as one amongst others. Even though, in the current "conventional globalization" there are new aspects brought by technology, it is a matter of similar empirebuilding as was the Roman one- and practice makes perfect - colonialism. From a social-philosophical perspective, the genuinely new aspects are not sufficient to make globalization irrevocable. Although fom the legal perspective it is a question of the legal system's substance being defined at the international level now, it is not necessarily permanent phenomenon. As opposed to international law, also informal actors participate in the formation of global law: corporations, NGO's and private individuals. But Heiskanen remarks that here "global" is actually restricted to the "West" or the sphere of liberal market economy.

The main challenge he perceives, is fitting together local and global regulation. Since conventional law is territorially defined, at the global level law becomes more and more abstract and less reflective of local needs. But Heiskanen sees globalization as an almost natural pendulum movement, that is in itself difficult to criticize but which can be, more or less, managed.
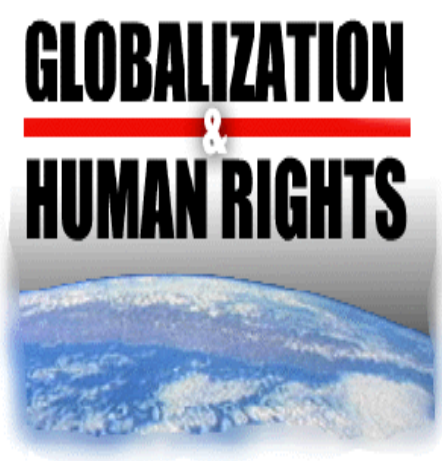

I know you are there

Veijo Heiskanen asked in his speech at the Law Graduate Study Conference: "Why is the world globalizing, "worldwidening" or becoming world wide only now? Hasn't the world always been as wide as itself, so world wide? If not, how wide has it been previously? The answer to this question comes down to the fact that the world has always been world wide, but only the technological development of the last decades has allowed a wider awareness of this fact to develop. The widening exchange of information has both enabled the world-widening of different sectors as well as made possible the discovery and analysis of these phenomena by specialists of different fields. But it is significant that this is not enough, and that "globality" is a collective feeling in our every-day lives. In a situation where our state has been taken away, as has the party and, seemingly, ideology as well, what would we do without globalization? We need to base our political awareness on something. Choose life. Get globalized. 